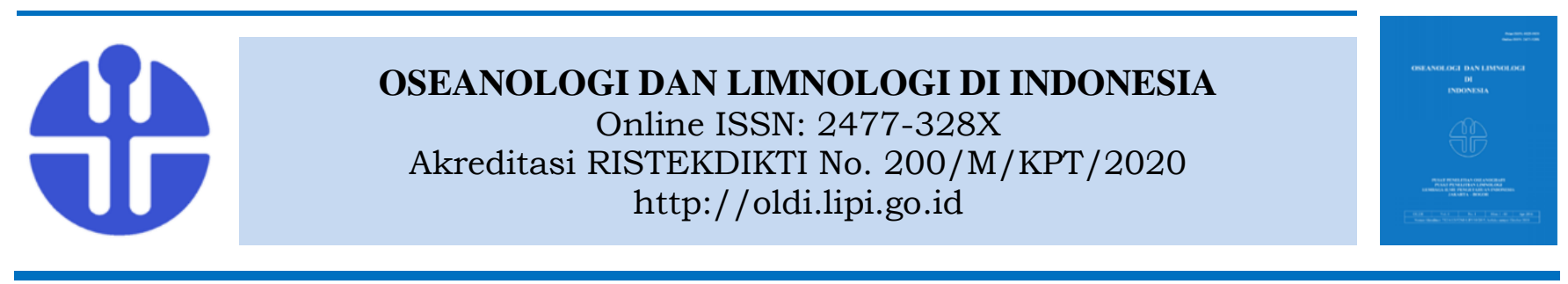

\title{
Bioakumulasi Merkuri (Hg) pada Lamun Enhalus acoroides dan Mangrove Rhizophora apiculata di Pulau Pari, Kepulauan Seribu
}

\author{
Anna Rejeki Simbolon', Triyoni Purbonegoro² \\ ${ }^{1,2}$ Pusat Penelitian Oseanografi, Lembaga Ilmu Pengetahuan Indonesia \\ Jalan Pasir Putih 1, Ancol Timur, Jakarta \\ Email: anna.rejeki.simbolon@lipi.go.id
}

Submitted 11August 2021. Reviewed 19August 2021. Accepted 20 September 2021. DOI: 10.14203/oldi.2021.v6i3.369

\begin{abstract}
Abstrak
Pencemaran logam berat khususnya logam Hg di Teluk Jakarta dikhawatirkan memberikan dampak negatif terhadap kualitas perairan di sekitar Perairan Teluk Jakarta salah satunya adalah Pulau Pari di Kepulauan Seribu. Lamun dan mangrove yang tumbuh di Pulau Pari dapat digunakan sebagai indikator pencemaran logam berat. Nilai bioakumulasi dan translokasi faktor logam $\mathrm{Hg}$ akan memberikan gambaran mengenai kemampuan tumbuhan dalam mengakumulasi logam berat di sekitarnya. Penelitian ini bertujuan untuk mengetahui biakumulasi dan translokasi faktor logam berat $\mathrm{Hg}$ pada tumbuhan lamun Enhalus acoroides dan mangrove Rhizophora apiculata di Pulau Pari, Kepulauan Seribu. Sampel lamun dan mangrove diambil pada lima titik pengambilan sampel melalui purposive sampling. Nilai bioakumulasi dihitung dengan menggunakan rasio dari konsentrasi logam di setiap bagian tubuh tumbuhan dan sedimen. Sementara itu, nilai translokasi faktor dihitung dengan rasio konsentrasi $\mathrm{Hg}$ pada setiap bagian tubuh tumbuhan (akar/rhizoma, batang, dan daun). Hasil penelitian ini menunjukkan nilai bioakumulasi pada lamun yaitu tidak terhingga (bioaccumulation factor, $\mathrm{BAF}=\infty$ ) dan pada mangrove yaitu 1,57 $(\mathrm{BAF}>1)$ ). Nilai faktor translokasi tertinggi pada daun lamun yaitu 3,86 (translocation factor, TF) >1) dan pada daun mangrove yaitu 2,84 (TF>1). Penelitian ini menunjukkan tumbuhan lamun dan mangrove tergolong sebagai tumbuhan bioakumulator dan hiperakumulator yang baik dan mengakumulasi logam berat khususnya $\mathrm{Hg}$ pada bagian atas tumbuhan yaitu daun.
\end{abstract}

Kata kunci: Logam berat, Hg, BAF, TF, Pulau Pari

\begin{abstract}
Bioaccumulation of Mercury (Hg) in Seagrass Enhalus acoroides and Mangrove Rhizophora apiculata in Pari Island, Seribu Islands. Heavy metal pollution, especially $\mathrm{Hg}$ metal in Jakarta Bay, is feared to have a negative impact on the quality of the waters around the Jakarta Bay waters, one of which is Pari Island in the Thousand Islands. Seagrass and mangroves plants distributed surrounding Pari Island can be used as indicators of heavy metal pollution. The value of bioaccumulation and translocation of $\mathrm{Hg}$ metal factors will provide an overview of the ability of plants to accumulate heavy metals in their surroundings. This study aims to determine the bioaccumulation and translocation of the heavy metal $\mathrm{Hg}$ factor in Enhalus acoroides seagrass and Rhizophora apiculata mangroves on Pari Island, Seribu Islands. Seagrass and mangrove samples were taken at five sampling points through purposive sampling. The bioaccumulation value was calculated using the ratio of the metal concentrations in each part of the plant body and sediment. Meanwhile, the translocation factor value was calculated by the ratio of $\mathrm{Hg}$ concentration in each part of the plant body (roots/rhizomes, stems, and leaves). The results of this study indicate that the bioaccumulation
\end{abstract}


value in seagrass is infinite (bioaccumulation factor, $\mathrm{BAF}=\infty$ ) and in mangroves is $1.57(\mathrm{BAF}>1)$. The highest translocation factor value in seagrass leaves is 3.86 (translocation factor, $\mathrm{TF}$ ) >1) and in mangrove leaves is $2.84(\mathrm{TF}>1)$. This study shows that seagrass and mangrove plants are classified as good bio accumulator and hyperaccumulator plants and accumulate heavy metals, especially $\mathrm{Hg}$ in the upper part of their bodies, namely leaves.

Keywords: Heavy metals, Hg, BAF, TF, Pari Island

\section{Pendahuluan}

Pencemaran logam berat merupakan salah satu pencemaran yang hingga kini menjadi perhatian serius di dunia. Tingginya aktivitas manusia (antropogenik) akan diikuti oleh meningkatnya limbah yang umumnya mengandung logam berat dan secara langsung maupun tidak langsung akan masuk ke wilayah perairan (Simbolon, 2018). Logam berat dalam kolom air dapat terakumulasi dalam sedimen dan biota melalui proses biokonsentrasi, bioakumulasi, dan biomagnifikasi (Simbolon, 2019). Konsentrasi logam berat yang terlalu tinggi pada lingkungan perairan dapat menyebabkan dampak toksik bagi biota perairan. Merkuri $(\mathrm{Hg})$ merupakan salah satu logam berat yang umumnya terdapat dalam limbah, misalnya dari hasil pembakaran (Huang et al., 2011), kegiatan industri batubara, pertambangan, limbah organik, dan berbagai kegiatan antropogenik lainnya (Fang \& Chen, 2010; Liu et al., 2011). Merkuri (Hg) yang berasal dari limbah masuk ke perairan dalam bentuk anorganik dan dapat berubah secara alami dalam air dan sedimen menjadi senyawa toksik organik yaitu methylmercury $(\mathrm{MeHg})$ yang dapat masuk ke organisme perairan (Mason et al., 2006; Voegborlo et al., 2011).

Kepulauan Seribu merupakan wilayah yang berbatasan langsung dengan perairan Teluk Jakarta. Aktivitas antropogenik seperti industri, pemukiman hingga pelabuhan yang tinggi di kawasan pesisir Teluk Jakarta dikhawatirkan memberikan dampak pencemaran ke perairan sekitarnya. Pulau Pari menjadi salah satu pulau di Kepulauan Seribu yang cukup rentan terhadap pencemaran baik yang berasal dari Teluk Jakarta maupun dari aktivitas manusia di pulau itu sendiri (Sachoemar, 2008). Pulau Pari memiliki luas $55,26 \mathrm{Ha}$ dan panjang garis pantai $8,5 \mathrm{~km}$ dengan karakteristik pantai berpasir $5,07 \mathrm{~km}$, pantai berbatu 2,27 km dan pantai mangrove $1,16 \mathrm{~km}$ (Hadiwijaya et al., 2013). Pulau Pari berada di atas rataan terumbu karang dengan pulau pulau kecil disekitarnya (P. Tikus, P. Burung, P. Tengah, P. Kongsi), sehingga membentuk gugusan pulau dengan beberapa laguna serta memiliki keunikan dengan tiga ekosistem tropika (mangrove, lamun, dan koral) yang menyebabkan tingginya keanekaragam hayati di pulau ini (P2O LIPI, 2016). Namun, tingginya tekananan lingkungan berdampak negatif terhadap kondisi perairan di Kepulauan Seribu. Logam berat khususnya Merkuri (Hg) diketahui telah terakumulasi pada sedimen dan biota di Pulau Pari (Purbonegoro \& Suratno, 2020; Suratno \& Irawan, 2018).

Logam berat tidak dapat dihilangkan dan dihancurkan namun dapat dikurangi dengan memanfaatkan tumbuhan (fitoremediasi). Sebagai salah satu pulau objek wisata, Pulau Pari memiliki eksosistem mangrove dan lamun yang cukup baik dan memiliki fungsi ekologis yang penting. Mangrove umumnya berfungsi sebagai hutan lindung dan ekowisata, selain itu mangrove juga dapat digunakan sebagai akumulator pencemar logam berat dengan kadar yang tinggi (BPLHD, 2014; Chaudhuri et al., 2013). Sementara itu, ekosistem lamun selain memiliki peran krusial dalam menahan gelombang laut, dan menjadi barrier (penghalang) bagi ekosistem terumbu karang, lamun juga diketahui dapat mengakumulasi logam berat yang terdapat di sedimen yang berasal dari daratan (Poedjirahajoe et al., 2013). Tumbuhan lamun Enhalus acoroides dan mangrove Rhizophora apiculata merupakan salah satu tumbuhan laut yang cukup banyak ditemukan di sekitar Pulau Pari (Suratno \& Irawan, 2018; Nadaa et al., 2021). Rhizophora apiculata merupakan salah satu jenis mangrove yang dapat menyerap logam berat dimana tumbuhan ini memiliki sarana pertumbuhan yang luas dan bervariasi sehingga dapat dijadikan salah satu tumbuhan dalam rangka pengendalian pencemaran logam berat (Subiandono et al., 2013). Sebagai salah satu jenis lamun yang umum diperairan tropis, Enhalus acoroides merupakan jenis lamun yang dapat digunakan untuk mengetahui tingkat akumulasi logam berat karena memiliki diferensiasi jaringan yang cukup untuk dianalisis (Ahmad et al., 2015a). Enhalus acoroides telah diketahui memiliki kemampuan dalam mengakumulasi logam berat $\mathrm{Cd}$, As, dan $\mathrm{Cu}, \mathrm{Hg}$, dan $\mathrm{Pb}$ (Ahmad et al., 2015a). Nilai BAF menunjukkan kemampuan suatu organisme dalam menyerap suatu jenis senyawa dari lingkungannya 
dimana laju penyerapan lebih besar dibandingkan laju pelepasannya. Sementara itu faktor translokasi atau Translocation Factor (TF) menunjukkan pola distribusi logam berat saat masuk ke dalam tubuh organisme menuju bagianbagian tertentu (Llagostera et al., 2011).

Penelitian mengenai kadar logam berat di Pulau Pari dan Teluk Jakarta telah dilakukan (Nugraha et al., 2017; Cordova et al., 2017; Simbolon, 2019; Purbonegoro \& Suratno, 2020). Sementara itu, konsentrasi logam berat khususnya Hg pada lamun telah dilakukan Suratno \& Irawan (2018) namun penelitan mengenai bioakumulasi dan faktor translokasi logam khususnya merkuri pada tumbuhan laut di Pulau Pari belum pernah dilakukan. Penelitian ini bertujuan untuk mengetahui bioakumulasi dan faktor translokasi pada lamun dan mangrove di Pulau Pari, Kepulauan Seribu, DKI Jakarta.

\section{Metodologi}

\section{Waktu dan lokasi pengambilan sampel}

Pengambilan sampel lamun dilakukan pada April 2016 sementara itu sampel mangrove diambil pada Februari 2017 di Pulau Pari, Kepulauan Seribu. Sampel diambil pada empat titik di sisi utara dan selatan pulau (Gambar 1). Lokasi pengambilan sampel ditentukan secara purposive sampling. Pemilihan lokasi di utara dan selatan P. Pari berdasarkan pertimbangan tingkat paparan pulau tersebut terhadap polutan dari Teluk Jakarta. Diasumsikan bagian selatan P. Pari lebih terpapar polutan dan sebaliknya bagian utara pulau tidak terlalu terpapar polutan dari Teluk Jakarta. Pengolahan sampel dan analisis $\mathrm{Hg}$ dilakukan di Laboratorium Oseanografi Kimia, Pusat Penelitian Oseanografi (P2O) LIPI, Jakarta.

Sampel tumbuhan yang diambil adalah akar/rhizoma, batang, dan daun. Sampel tumbuhan dipilih dan diambil menggunakan pisau, dibersihkan dengan air tawar, dimasukkan kedalam plastik sampel, dan ditutup dengan rapat, serta diberi label. Sampel bagian tumbuhan diambil sebanyak 1 tumbuhan dengan berat kurang lebih 20-30 mg per bagian tumbuhan. Sementara itu, sampel sedimen diambil dengan menggunakan sendok stainless stell yang sudah dibersihkan sebanyak kurang lebih $30 \mathrm{mg}$ di setiap lokasi stasiun pengambilan. Sampel kemudian dimasukkan ke dalam coolbox/freezer untuk menjaga kelembaban sampel dan menghindari kontaminasi sampai sebelum diolah dan dianalisis. Pengambilan sampel sedimen, akar/rhizoma, batang dan daun dilakukan dengan tiga kali ulangan pada setiap stasiun.

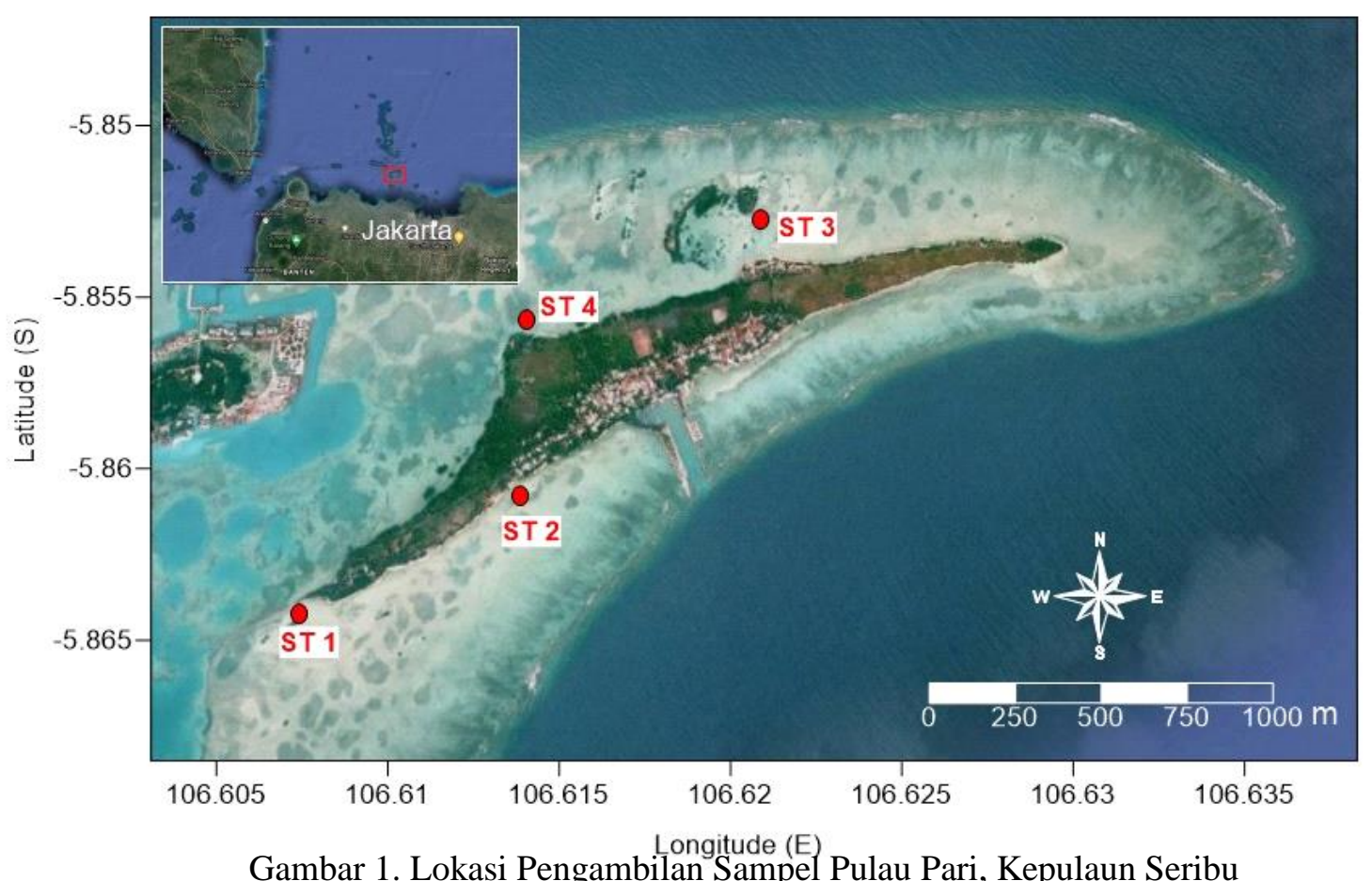

Gambar 1. Lokasi Pengambilan Sampel Pulau Pari, Kepulaun Seribu Figure 1. Sampling Location Pari Island, Thousand Islands

\section{Preparasi Sampel dan Analisis Data}

Sebanyak 20-30 mg sampel kering dan telah dihaluskan dimasukkan ke dalam boat (wadah sampel untuk proses analisis $\mathrm{Hg}$ ). Pengukuran logam dilakukan tiga kali ulangan dalam setiap sampel. Boat diletakkan di terminal 
(wadah yang dapat menampung 10 buah boat) lalu dilakukan proses pengukuran konsentrasi $\mathrm{Hg}$ dengan mercury analyzer NIC MA-3000. Proses analisis ini didasarkan pada metode USEPA 7473 Analisis Merkuri dalam padatan dan larutan dengan Dekomposisi Termal (NIC, 2015). Prinsip proses kerja mercury analyzer terbagi menjadi tiga bagian antara lain heating furnace $(\mathrm{H}-1)$ yaitu proses pemanasan dan penguapan sampel; decomposing furnace $(\mathrm{H}-2)$ yaitu proses penguraian dan pemisahan senyawa $\mathrm{Hg}$ dan bukan $\mathrm{Hg}$; serta mercury collector (H-3) yaitu pengumpulan, pengembunan dan pemurnian gas $\mathrm{Hg}$. Gas $\mathrm{Hg}$ yang terkumpul akan dipanaskan lagi, dan dilakukan pengukuran nilai konsentrasi dengan menggunakan absorbansi pada panjang gelombang 253,7 nm (NIC, 2015). Data hasil analisis konsentrasi $\mathrm{Hg}$ sampel ditampilkan pada layar komputer. Mercury analyzer telah dikalibrasi dan divalidasi untuk memastikan alat berfungsi baik. Metode kalibrasi dilakukan dengan menggunakan SRM 1515: Apple Leaves yang telah disertifikasi oleh National Institut of Standards and Technology (NIST) dan PACS-3: Marine sediment certified reference material yang telah disertifikasi oleh National Research Council Canada.

Bioaccumulation Factor (BAF) atau faktor akumulasi sedimen-organisme digunakan untuk mengevaluasi kapasitas akumulasi logam dalam organisme dari sedimen. BAF ditentukan dengan persamaan (1), dimana $\mathrm{Cp}$ adalah konsentrasi logam pada bagian tubuh tumbuhan $(\mu \mathrm{g} / \mathrm{kg}-\mathrm{bk})$ dan Cs adalah konsentrasi logam pada sedimen ( $\mu \mathrm{g} / \mathrm{kg}-\mathrm{bk})$, bk menunjukkan konsentrasi total merkuri dalam bentuk berat kering. (Radulescu et al., 2013). Kategori tanaman menurut Baker (1981) ialah: $\mathrm{BAF}<1$ = tanaman sebagai ekskluder (menahan laju dibagian akar); $\mathrm{BAF}=1=$ tanaman sebagai indikator (akumulasi logam pada tanaman dan tanah hampir sama jumlahnya); dan BAF $>1=$ tanaman sebagai akumulator (akumulasi logam di pucuk tanaman tinggi dibanding akar tanaman).

Faktor translokasi atau Translocation Factors (TF) merupakan perbandingan antara konsentrasi $\mathrm{Hg}$ pada akar, batang, daun, dan bunga. Nilai TF digunakan untuk mengetahui perpindahan akumulasi $\mathrm{Hg}$ dari akar ke tunas (Rezvani \& Zaefarian, 2011). Nilai TF dalam penelitian ini dihitung dari akar ke batang, akar ke daun, akar ke bunga, dan batang ke daun. Nilai TF ditentukan dengan persamaan (2) dimana $\mathrm{Cx}$ adalah konsentrasi rata-rata $\mathrm{Hg}$ pada tunas atau shoot (batang, daun) ( $\mu \mathrm{g} / \mathrm{kg}-\mathrm{bk})$; dan Cy adalah konsentrasi rata-rata $\mathrm{Hg}$ pada bagian pendistribusi atau root (akar) ( $\mu \mathrm{g} / \mathrm{kg}-\mathrm{bk})$. Determinasi sifat translokasi menurut Baker (1981) ialah: $\mathrm{TF}<1=$ mekanisme fitostabilisasi (penurunan mobilitas polutan melalui pembentukan senyawa yang lebih kompleks namun mudah untuk diadsorpsi oleh tumbuhan di daerah rizosfer); dan $\mathrm{TF}>1=$ mekanisme fitoekstraksi (penyerapan polutan oleh akar dan ditranslokasi bagian jaringan tanaman) dengan karakteristik tanaman hiperakumulator (kemampuan mengakumulasi logam dalam jumlah yang tinggi) (Tuapattinaya et al., 2016). Uji beda nyata antar masing-masing morfologi tumbuhan menggunakan uji Anova pada SPSS versi 21.

$$
\begin{aligned}
& \mathrm{BAF}=\frac{c p}{C s} \\
& \mathrm{TF}=\frac{C x}{C y}
\end{aligned}
$$

\section{Hasil}

\section{Konsentrasi, Biakumulasi, dan Faktor Translokasi Hg pada Lamun Enhalus acoroides}

Dari empat stasiun pengambilan sampel, hanya stasiun 1 yang memiliki ekosistem lamun dan mangrove. Lamun ditemukan pada stasiun 1, 2 , dan 3, sementara mangrove ditemukan pada stasiun 1 dan 4. Konsentrasi rata-rata $\mathrm{Hg}$ pada sedimen dan tumbuhan lamun disajikan pada Gambar 2 dan pada mangrove pada Gambar 3.

Konsentrasi $\mathrm{Hg}$ pada sedimen di ekosistem lamun di setiap stasiun menunjukkan nilai sangat rendah atau tidak terdeteksi (ttd). Logam $\mathrm{Hg}$ terakumulasi tertinggi pada bagian daun lamun $E$. acoroides (Gambar 1) yaitu dengan rata-rata $10,50 \pm 3,40 \mu \mathrm{g} / \mathrm{kg}$-bk diikuti bagian batang yaitu $5,62 \pm 2,82 \mu \mathrm{g} / \mathrm{kg}$-bk serta akar yaitu $2,74 \pm 1,41$ $\mu \mathrm{g} / \mathrm{kg}$-bk dan terendah pada bagian rhizoma yaitu $0,43 \pm 0,60 \mu \mathrm{g} / \mathrm{kg}$-bk (Tabel 1).

BAF pada lamun di seluruh stasiun menghasilkan nilai tidak terhingga karena konsentrasi merkuri di sedimen sangat kecil (tidak terdeteksi). Sementara itu, nilai TF menunjukkan nilai yang berbeda-beda. Nilai TF tertinggi terdapat pada akar-daun yaitu senilai 3,84 dan terendah pada akar-rhizoma yaitu senilai 0,16 


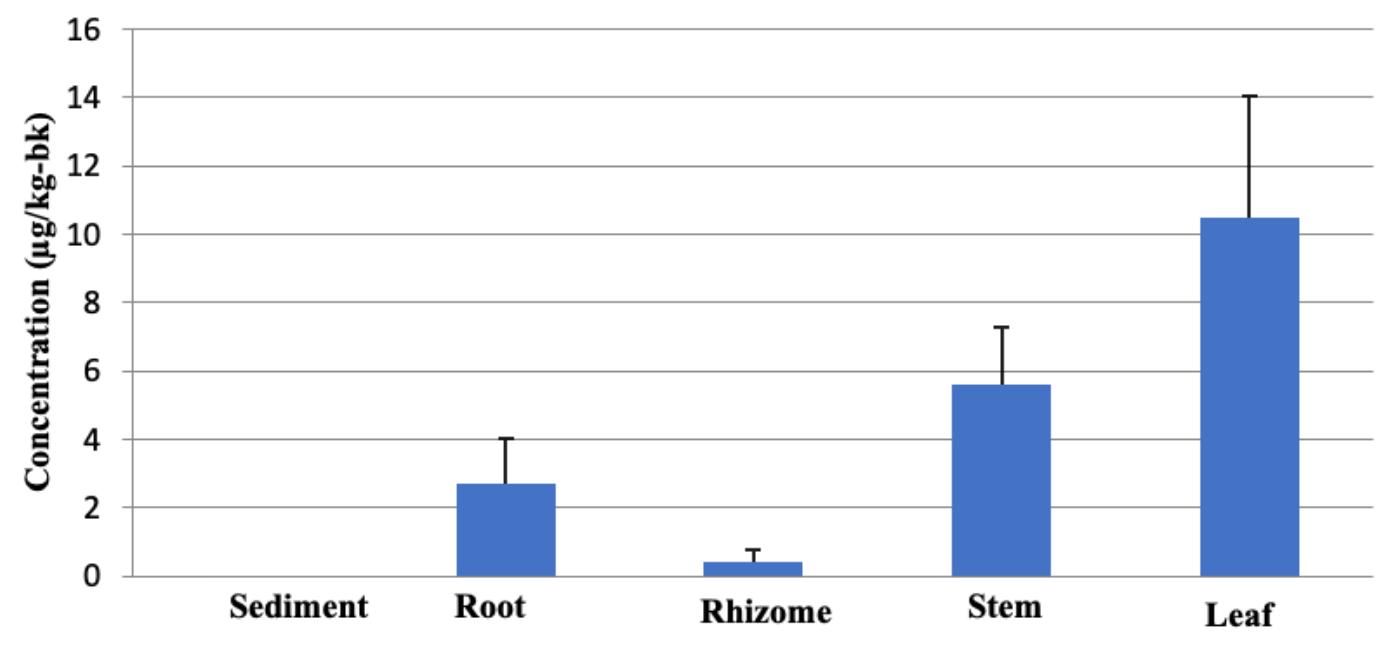

Gambar 2. Konsentrasi rata-rata $\mathrm{Hg}$ pada sedimen dan Lamun E. acoroides di Pulau Pari, Kepulauan Seribu Figure 2. Mean concentration of $\mathrm{Hg}$ in E. acoroides Seagrass Ecosystem in Pari Island, Kepulauan Seribu

Tabel 1. Konsentrasi rata-rata Hg, Nilai BAF dan TF pada sedimen dan lamun E. acoroides di Pulau Pari, Kepulauan Seribu

Table 1. Mean concentration of $\mathrm{Hg}, \mathrm{BAF}$ and $\mathrm{TF}$ values on sediments and E. acoroides Pari Island, Kepulauan Seribu

\begin{tabular}{llllll}
\hline & \multicolumn{1}{c}{ Body Part } & \multicolumn{1}{c}{ Station 1 } & \multicolumn{1}{c}{ Station 2 } & \multicolumn{1}{c}{ Station 3 } & \multicolumn{1}{c}{ Mean } \\
\hline Concentratio & Sediment & No detection & No detection & No detection & No detection \\
$\mathrm{n}$ & Root & $4.02^{\mathrm{a}} \pm 0.77$ & $1.41^{\mathrm{b}} \pm 1.24$ & $2.77^{\mathrm{c}} \pm 0.72$ & $2.74 \pm 1.41$ \\
$\mathrm{Hg}(\mu \mathrm{g} / \mathrm{kg}-$ & Rhizome & $0.62^{\mathrm{a}} \pm 0.62$ & $0.66^{\mathrm{a}} \pm 0.68$ & Ttd & $0.43 \pm 0.60$ \\
$\mathrm{bk})$ & Stem & $6.48^{\mathrm{a}} \pm 2.65$ & $6.66^{\mathrm{a}} \pm 2.97$ & $3.71^{\mathrm{b}} \pm 1.82$ & $5.62 \pm 2.82$ \\
$\mathrm{BAF}$ & Leaf & $10.36^{\mathrm{a}} \pm 2.47$ & $14.11^{\mathrm{b}} \pm 1.28$ & $7.03^{\mathrm{c}} \pm 1.28$ & $10.50 \pm 3.40$ \\
& Sediment-Root & $\infty$ & $\infty$ & $\infty$ & $\infty$ \\
& Sediment- & $\infty$ & $\infty$ & $\infty$ & $\infty$ \\
& Rhizome & & & & \\
$\mathrm{TF}$ & Sediment-Stem & $\infty$ & $\infty$ & $\infty$ & $\infty$ \\
& Sediment-Leaf & $\infty$ & $\infty$ & $\infty$ & $\infty$ \\
& Root-Rhizome & 0.15 & 0.47 & 0.00 & 0.16 \\
& Root-Stem & 1.61 & 4.71 & 1.34 & 2.05 \\
& Root-Leaf & 2.58 & 9.99 & 2.53 & 3.84 \\
\hline
\end{tabular}

Tanda abjad superscript yang berbeda pada setiap kolom menandakan perbedaan yang signifikan $(\mathrm{p}<0.05)$

\section{Konsentrasi, Biakumulasi dan Faktor Translokasi Hg pada Mangrove Rhizophora apiculata}

Konsentrasi rata-rata $\mathrm{Hg}$ pada sedimen di ekosistem mangrove dalam penelitian ini yaitu 51,16 $\mu \mathrm{g} / \mathrm{kg}$-bk. Konsentrasi $\mathrm{Hg}$ tertinggi ditemukan pada daun yaitu berkisar $70,07 \mu \mathrm{g} / \mathrm{kg}$ bk, pada akar 25,92 $\mu \mathrm{g} / \mathrm{kg}$-bk, dan terendah pada batang 17,49 $\mu \mathrm{g} / \mathrm{kg}$-bk (Tabel 2). Nilai BAF pada mangrove tertinggi pada daun yaitu $1,571 \pm 0,84$ $(\mathrm{BAF}>1)$ sementara bagian lainnya $\mathrm{BAF}<1$ (Tabel 1). Nilai TF pada tumbuhan mangrove tertinggi pada bagian akar-daun yaitu dengan rata-rata $2,814 \pm 0,69 \quad(\mathrm{TF}>1)$, sementara itu bagian morfologi lainnya berkisar antara 0,245-0,886 $(\mathrm{TF}<1)($ Tabel 1). 


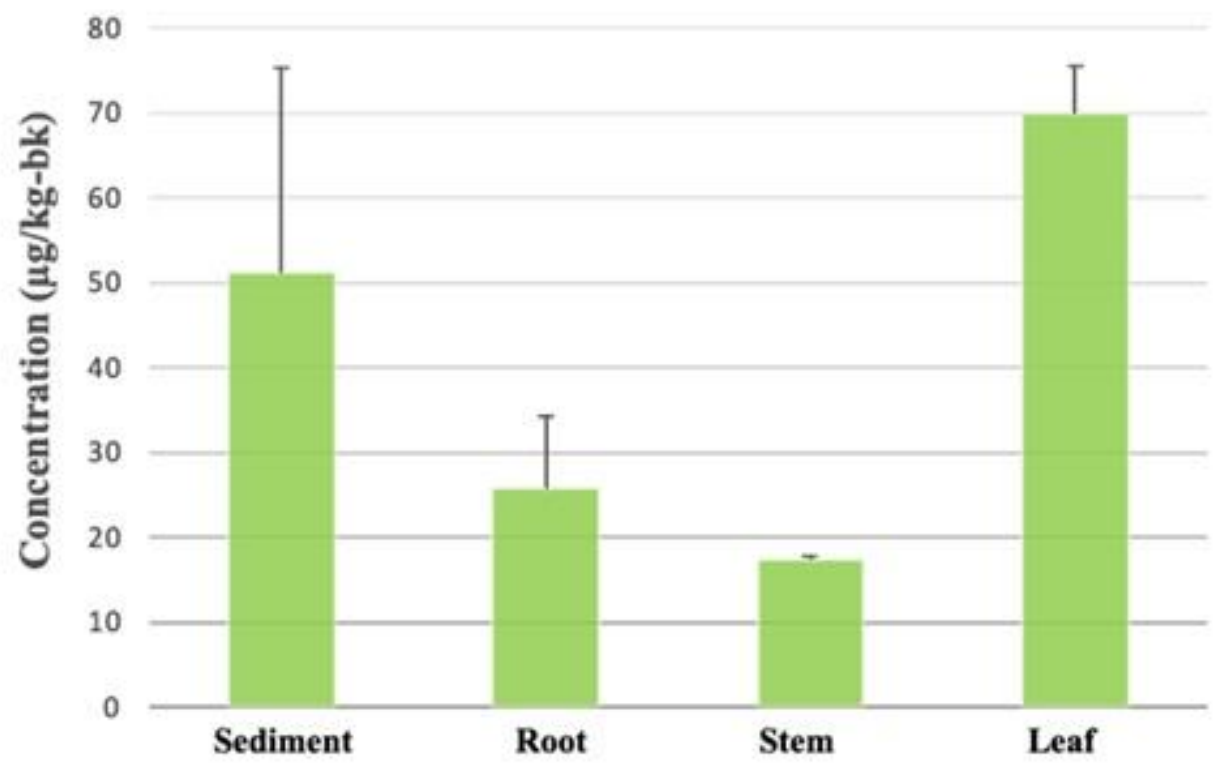

Gambar 3. Konsentrasi rata-rata Hg pada sedimen dan Mangrove Rhizophora apiculata di Pulau Pari, Kepulauan Seribu

Figure 3. Mean concentrations of $\mathrm{Hg}$ in the Rhizophora apiculata Mangrove Ecosystem in Pari Island, Seribu Islands

Tabel 2. Konsentrasi rata-rata $\mathrm{Hg}$, Nilai BAF dan TF pada sedimen dan R. apiculata di Pulau Pari, Kepulauan Seribu

Table 2. Mean concentration of $\mathrm{Hg}, \mathrm{BAF}$ and $\mathrm{TF}$ values on sediment and $R$. apiculata in Pari Island, Kepulauan Seribu

\begin{tabular}{lllll}
\hline & Body Part & \multicolumn{1}{c}{ Station 1 } & \multicolumn{1}{c}{ Station 4 } & \multicolumn{1}{c}{ Mean } \\
\hline Concentration & Sediment & $34.052^{*}$ & $68.276^{*}$ & $51.164 \pm 24.2$ \\
$\mathrm{Hg}(\mu \mathrm{g} / \mathrm{kg}$-bk $)$ & Root & $31.823^{\mathrm{a}} \pm 1.81$ & $20.033^{\mathrm{b}} \pm 1.502$ & $25.927 \pm 8.33$ \\
& Stem & $17.231^{\mathrm{a}} \pm 1.2$ & $17.756^{\mathrm{a}} \pm 0.085$ & $17.493 \pm 0.37$ \\
& Leaf & $73.932^{\mathrm{a}}$ & $66.222^{\mathrm{b}} \pm 0.392$ & \\
$\mathrm{BAF}$ & & \pm 0.671 & & $70.077 \pm 5.45$ \\
& Sediment-Root & 0.934 & 0.293 & $0.614 \pm 0.45$ \\
& Sediment-Stem & 0.506 & 0.260 & $0.383 \pm 0.17$ \\
$\mathrm{TF}$ & Sediment-Leaf & 2.171 & 0.966 & $1.571 \pm 0.84$ \\
& Root-Stem & 0.541 & 0.886 & $0.714 \pm 0.24$ \\
& Root-Leaf & 2.323 & 3.305 & $2.814 \pm 0.69$ \\
\hline
\end{tabular}

*Sumber: Cordova dan Muhtadi 2017

Tanda abjad superscript yang berbeda pada setiap kolom menandakan perbedaan yang signifikan $(\mathrm{p}<0.05)$

\section{Pembahasan}

\section{Konsentrasi, Biakumulasi dan Faktor Translokasi Hg pada Lamun Enhalus acoroides}

Penelitian ini menunjukkan konsentrasi $\mathrm{Hg}$ pada sedimen di ekosistem lamun sangat kecil (tidak terdeteksi). Ahmad et al. (2015b) menyatakan logam $\mathrm{Hg}$ merupakan salah satu logam berat yang ditemukan lebih sedikit dibandingkan logam lain, baik di lingkungan alami maupun dilingkungan tercemar. Bonanno dan Di Martino (2016) juga menemukan logam $\mathrm{Hg}$ tidak terdeteksi baik pada sedimen, kolom air dan tubuh lamun di Pesisir Laut Mediterania. Hal yang sama ditemukan pada konsentrasi logam $\mathrm{Hg}$ di sedimen Teluk Jakarta yaitu $0,489 \mathrm{mg} / \mathrm{bk}-\mathrm{kg}$ (Simbolon, 2019) dan konsentrasi $\mathrm{Hg}$ pada sedimen di Pulau Bulu, Maluku, yaitu 0,501 $\mathrm{mg} / \mathrm{kg}$ (Natsir \& Rijal, 2020). Pemerintah 
Indonesia belum memiliki baku mutu sedimen bagi organisme laut, sehingga penelitian ini mengacu pada baku mutu yang dikeluarkan oleh Pemerintah Australia mengenai baku mutu sedimen di perairan laut dimana nilai tersebut masih dibawah baku mutu berdasarkan ANZECC dan ARMCANZ (2000) yaitu $150 \mathrm{mg} / \mathrm{kg}$. Akumulasi logam di sedimen dipengaruhi oleh $\mathrm{pH}$, kemampuan ion, masukan antropogenik, tipe, dan konsentrasi ligan organik dan anorganik, serta ukuran dan distribusi partikel sedimen (Davies et al., 1991). Penelitian ini menunjukkan konsentrasi $\mathrm{Hg}$ pada sedimen di ekosistem lamun lebih kecil dibandingkan pada ekosistem mangrove. Hal ini diduga disebabkan perbedaan dalam pengambilan sampel sedimen pada waktu yang berbeda. Sedimen di ekosistem mangrove diambil pada April 2016, sedangkan sedimen di ekosistem lamun diambil pada Februari 2017.

Logam $\mathrm{Hg}$ di tumbuhan lamun tertinggi pada bagian daun, hal yang sama juga ditemukan pada E. acoroides pada Pulau Tunda, Perairan Banten dimana akumulasi logam tertinggi pada bagian daun (Zamani et al., 2018). Suratno \& Irawan (2018) juga menemukan hal yang sama dimana konsentrasi $\mathrm{Hg}$ pada tubuh lamun tertinggi pada bagian daun. Struktur vegetasi lamun yang seluruh tubuhnya terendam pada air menyebabkan logam berat yang berasal dari kolom air terakumulasi pada seluruh jaringan tumbuhan (Ahmad et al., 2015b). Jaringan epidermis pada daun lamun memiliki kemampuan untuk mengabsorbsi logam berat langsung dari kolom air (Larkum et al., 2006). Tingginya konsentrasi $\mathrm{Hg}$ pada daun juga disebabkan lamun memiliki banyak ligan dan mampu mentranslokasikan logam tersebut bersama elemen-elemen lain melalui jaringan pengangkut (xylem) (Tuapattinaya et al., 2016). Hal yang berbeda ditemukan pada konsentrasi $\mathrm{Hg}$ pada $E$. acoroides di Perairan Kayeli, Pulau Buru, Maluku dimana konsentrasi $\mathrm{Hg}$ pada akar lebih tinggi dibandingkan pada rhizoma dan daun (akar>rhizoma>daun). Larkum et al. (2006) menambahkan bahwa logam berat masuk ke tubuh lamun melalui dua cara yaitu logam berat dari kolom air yang masuk ke jaringan daun lalu ke rhizoma dan logam berat dari sedimen yang masuk melalui akar lalu ke daun. Selain itu proses fisiologis tumbuhan dalam mengakumulasi logam berat dimulai pada bagian akar (Natsir \& Rijal, 2020). Pada akar terjadi penebalan jaringan endodermis dan eksodermis sebagai proses respon terhadap akumulasi logam berat, logam berat diserap melalui proses absropsi pasif pada stomata dan kutikula serta transportasi aktif hingga terakumulasi pada daun (Tupan \& Azrianingsih,
2016). Proses bioakumulasi logam berat pada lamun dipengaruhi oleh sedimen dan air, jenis partikel sedimen, reaksi redoks, bahan organik terlarut (dissolved organic matter) dan pola musim (Larkum et al., 2006).

Nilai BAF menunjukkan kemampuan suatu organisme dalam menyerap suatu jenis senyawa dari lingkungannya dimana laju penyerapan lebih besar dibandingkan laju pelepasannya. Konsentrasi logam merkuri di sedimen yang sangat kecil dibandingkan dengan konsentrasi merkuri dibagian tubuh lamun menunjukan kemampuan lamun sebagai bioakumulator logam merkuri (fitoremediator). Penelitian ini menunjukkan kemampuan E. acoroides sebagai bioindikator dalam mengakumulasi logam $\mathrm{Hg}$ di Pulau Pari sejalan dengan penelitian Natsir \& Rajali (2020) pada Perairan Kayeli, Pulau Buru, Maluku. Faktor translokasi (TF) menunjukkan pola distribusi logam berat saat masuk ke dalam tubuh organisme menuju bagian-bagian tertentu. TF dipengaruhi oleh sifat logam dan fisiologi tumbuhan (Llagostera et al., 2011). Nilai TF pada E. acoroides tertinggi terdapat pada akar-daun, seperti diketahui bagian daun dapat mengakumulasi logam yang berasal dari akar melalui transport aktif dan mengakumulasi logam merkuri dari kolom air. Sementara TF bagian rhizoma memiliki nilai terendah karena seluruh bagian rhizoma berada dalam sedimen dan hanya mengakumulasi logam yang berasal dari akar, serta meneruskan proses translokasi internal aktif dari akar menuju bagian ujung tumbuhan seperti daun, buah dan bunga (Ahmad et al., 2015a). Nilai $T F>1$ pada bagian akar-daun dan akarbatang menunjukkan konsentrasi $\mathrm{Hg}$ pada bagian daun dan batang lebih besar dibandingkan dengan di akar dan terjadi proses translokasi logam dari akar menuju kedua bagian tersebut. Nilai TF $>1$ menunjukkan bahwa tumbuhan tersebut berpotensi memiliki sifat fitoekstraksi dan hiperakumulator (Tuapattinaya et al., 2016).

\section{Konsentrasi, Biakumulasi, dan Faktor Translokasi Hg pada Mangrove Rhizophora apiculata}

Konsentrasi $\mathrm{Hg}$ di sedimen tumbuhan mangrove masih bawah nilai rata-rata konsentrasi $\mathrm{Hg}$ dalam sedimen alami, yaitu $<80 \mu \mathrm{g} / \mathrm{kg}$ (Taylor, 1964). Selain itu, nilai tersebut juga masih berada di bawah baku mutu dalam pedoman mutu ANZECC dan ARMCANZ (2000), yaitu < $150 \mu \mathrm{g} / \mathrm{kg}$. Alloway \& Ayres (1995) menyatakan kisaran normal konsentrasi logam berat dalam sedimen dan tumbuhan adalah 10-300 $\mu \mathrm{g} / \mathrm{kg}$, sehingga konsentrasi $\mathrm{Hg}$ pada sedimen dan mangrove $R$. apiculata juga masih 
berada dalam kisaran normal. Konsentrasi $\mathrm{Hg}$ pada tumbuhan mangrove terendah terdapat pada bagian batang, hal ini terjadi karena batang hanya tempat sementara untuk $\mathrm{Hg}$ dan nutrien yang terangkut dari akar, lalu disalurkan lagi menuju daun melalui jaringan xilem (Ding et al., 2011). Kemampuan mangrove dalam mengakumulasi logam berat dalam sedimen dipengaruhi beberapa faktor antara lain kemampuan spesies mangrove tertentu, kondisi lingkungan, umur atau ukuran pohon. Peningkatan kandungan logam berat dengan meningkatnya kelas diameter pohon mangrove (diameter $<10 \mathrm{~cm}$ sampai $21-30 \mathrm{~cm}$ ). Kandungan logam berat selanjutnya akan mengalami penurunan dengan meningkatnya kelas umur yang disebabkan perbedaan sifat suatu logam berat tertentu, lalu mempengaruhi perilaku yang berbeda juga di dalam tubuh setiap spesies mangrove (Kristanti et al., 2007). Konsentrasi Hg tertinggi pada bagian daun. Logam $\mathrm{Hg}$ dalam sedimen diabsorpsi oleh akar, lalu masuk kedalam pembuluh xylem dan diangkut ke daun melalui aliran transpirasi hingga menumpuk di daun. Peningkatan konsentrasi $\mathrm{Hg}$ pada daun juga dipengaruhi oleh penempelan partikel $\mathrm{Hg}$ dari udara yang masuk ke daun melalui stomata (Ding et al., 2011).

Secara keseluruhan nilai BAF pada mangrove kurang dari $1(\mathrm{BAF}<1)$ menunjukkan mangrove termasuk dalam tumbuhan bioakumulator rendah dalam mengakumulasi logam Hg. Rendahnya nilai BAF menunjukkan tingkat kontaminasi $\mathrm{Hg}$ pada mangrove di daerah ini masih tergolong rendah, kemungkinan disebabkan wilayah ini masih jauh dari sumber utama pencemaran $\mathrm{Hg}$ yaitu perindustrian (Hadiwijaya et al., 2013). Nilai TF pada tumbuhan mangrove tertinggi pada bagian akardaun. Logam $\mathrm{Hg}$ diserap melalui akar dan menumpuk di daun sesuai dengan konsentrasi $\mathrm{Hg}$ pada daun yang paling tinggi diantara bagian morfologi lainnya. Hal yang sama juga terlihat pada Analuddin et al. (2017) dimana faktor translokasi logam $\mathrm{Hg}$ tertinggi pada bagian daun R.apiculata di kawasan pesisir Sulawesi Tenggara. Penumpukkan logam berat pada daun mangrove merupakan salah satu bentuk adaptif mangrove dalam mengatasi toksisitas logam $\mathrm{Hg}$ dalam tubuhnya, dengan menyimpan logam dalam daun dan pada saat konsentrasinya telah melampaui batas ambang yang di tolerir daun mangrove akan mudah rontok (Martuti et al., 2016).

\section{Perbandingan Konsentrasi Hg pada Lamun dan Mangrove dari Berbagai Lokasi}

Lokasi ekosistem mangrove dan lamun dari sumber pencemar mempengaruhi konsentrasi $\mathrm{Hg}$ pada tubuh tumbuhan. Konsentrasi $\mathrm{Hg}$ pada $R$. apiculata di Pulau Pari lebih kecil dibandingkan dengan di Perairan Bontang dan Sungai Donan (Tabel 3). Mangrove di perairan Bontang berlokasi dekat dengan kegiatan industri seperti pabrik Gas, (PT Badak Natural Gas Liquefaction), pabrik Pupuk (PT Pupuk Kaltim), serta industri kecil lainnya (Kristanti et al., 2007), demikian dengan di Sungai Donan dimana sepanjang sungai terdapat industri besar kilang minyak dan pabrik semen (Heriyanto \& Subiandono, 2011). Ekosistem mangrove di Pulau pari dan Sungai Segoro Anak umumnya dikelilingi oleh pemukiman penduduk dan aktivitas pariwisata sehingga konsentrasi $\mathrm{Hg}$ relatif kecil. Konsentrasi $\mathrm{Hg}$ pada sedimen di ekosisten lamun Pantai Kayeli lebih tinggi dibandingkan di Pulau Pari, hal ini disebabkan penggunaan merkuri oleh para penambang emas tradisional di sekitar Sungai Wacapo yang menggunakan cairan merkuri untuk mengolah emas (Natsir et al., 2020). Sementara itu, tingginya konsentrasi $\mathrm{Hg}$ pada lamun Enhalus acoroides di Muara Sungai Pulai disebabkan banyaknya proyek pengembangan dan cepatnya daerah urbanisasi sepanjang Selat Malaka (Ahmad et al., 2015b).

Sebagai tumbuhan bioindikator, tumbuhan lamun khususnya jenis $E$. acoroides dan mangrove jenis $R$. apiculata dapat mengakumulasi logam berat $\mathrm{Hg}$ di Pulau Pari dengan baik. sehingga dapat dikembangkan dalam rangka pengelolaan dan pengendalian pencemaran logam berat di daerah pesisir. Meskipun konsentrasi logam $\mathrm{Hg}$ di ekosistem mangrove dan lamun masih sesuai dengan baku mutu, namun pengelolaan limbah logam berat harus tetap dilakukan dengan baik dan berhati-hati karena apabila konsentrasinya semakin tinggi akan membahayakan dan organisme di perairan tersebut. 
Tabel 3. Perbandingan Konsentrasi Hg pada lamun dan mangrove saat penelitian dengan perairan lain Table 3. Comparison of $\mathrm{Hg}$ concentrations in seagrass and mangroves during research with other waters

\begin{tabular}{|c|c|c|c|c|c|}
\hline Plants & Location & Body Part & $\begin{array}{c}\text { Mean } \\
\text { concentration } \\
(\mu \mathrm{g} / \mathrm{kg})\end{array}$ & $\begin{array}{c}\text { Year of } \\
\text { sampling }\end{array}$ & Reference \\
\hline \multirow{12}{*}{$\begin{array}{c}\text { Mangrove } \\
\text { Rhizopora } \\
\text { apiculata }\end{array}$} & Pari Island, & Root & $25.927 \pm 8.33$ & \multirow[t]{3}{*}{2017} & \multirow{3}{*}{$\begin{array}{l}\text { Research } \\
\text { present }\end{array}$} \\
\hline & Kepulauan Seribu & Stem & $17.493 \pm 0.37$ & & \\
\hline & & Leaf & $70.077 \pm 5.45$ & & \\
\hline & South Bontang & Root & 140.3 & \multirow[t]{3}{*}{2005} & \multirow{3}{*}{$\begin{array}{l}\text { Kristanti et al., } \\
2007\end{array}$} \\
\hline & Waters, East & Stem & 32.3 & & \\
\hline & Kalimantan & Leaf & 133.3 & & \\
\hline & Donan River, & Root & 216 & \multirow[t]{6}{*}{2010} & \multirow{6}{*}{$\begin{array}{l}\text { Heriyanto \& } \\
\text { Subiandono, } \\
2011\end{array}$} \\
\hline & Central Java & Stem & 4590 & & \\
\hline & & Leaf & 134 & & \\
\hline & Segoro Anak & Root & $<0.1$ & & \\
\hline & River, East Java & Stem & $<0.1$ & & \\
\hline & & Leaf & $<0.1$ & & \\
\hline \multirow{10}{*}{$\begin{array}{l}\text { Lamun } \\
\text { Enhalus } \\
\text { acoroides }\end{array}$} & Pari Island, & Sediment & $\operatorname{ttd}$ & \multirow{5}{*}{$2016-2017$} & \multirow{5}{*}{$\begin{array}{l}\text { Research } \\
\text { present }\end{array}$} \\
\hline & Kepulauan Seribu & Root & $2.74 \pm 1.41$ & & \\
\hline & & Rhizome & $0.43 \pm 0.60$ & & \\
\hline & & Stem & $5.62 \pm 2.82$ & & \\
\hline & & Leaf & $10.50 \pm 3.40$ & & \\
\hline & Pari Island & Root & $11.61 \pm 1.16$ & \multirow[t]{3}{*}{2017} & Suratno \\
\hline & & Rhizome & $19.11 \pm 0.49$ & & \multirow{2}{*}{ Irawan, 2018) } \\
\hline & & Leaf & $16.42 \pm 3.15$ & & \\
\hline & $\begin{array}{l}\text { Kayeli Beach } \\
\text { Water, Maluku }\end{array}$ & Sediment & 0.501 & 2020 & $\begin{array}{l}\text { Natsir \& Rajali, } \\
2020\end{array}$ \\
\hline & $\begin{array}{l}\text { Pulai River Johor, } \\
\text { Malaysia }\end{array}$ & $\begin{array}{l}\text { E. } \\
\text { acoroides }\end{array}$ & $46 \pm 41$ & 2011-2012 & $\begin{array}{l}\text { Ahmad et al., } \\
2015 \text { b }\end{array}$ \\
\hline
\end{tabular}

\section{Kesimpulan}

Penelitian ini menyimpulkan bahwa konsentrasi logam $\mathrm{Hg}$ baik pada sedimen dan tubuh tumbuhan lamun dan mangrove masih dalam kisaran alami dan dibawah baku mutu. Tumbuhan lamun dan mangrove tergolong sebagai bioakumulator rendah dan dapat digunakan sebagai biakumulator logam $\mathrm{Hg}$ di Pulau Pari, Kepulauan Seribu. Nilai TF kedua tumbuhan ini menunjukkan sifat hiperakumulator (TF>1) yang cenderung mengakumulasi logam $\mathrm{Hg}$ lebih banyak pada bagian daun. Penelitian selanjutnya diharapkan dapat mengukur konsentrasi $\mathrm{Hg}$ pada kolom air laut sehingga gambaran bioakumulasi dan faktor translokasi $\mathrm{Hg}$ di ekosistem lamun dan mangrove lebih menyeluruh.

\section{Persantunan}

Ucapan terima kasih disampaikan kepada Kepala Pusat Penelitian Oseanografi, Lembaga Ilmu Pengetahuan Indonesia (LIPI) yang mengizinkan penelitian ini berlangsung. Ucapan terima kasih juga disampaikan kepada Debby Deswanto dan Dio Andikapadrya Kautsar yang telah membantu dalam pengambilan dan analisis sampel. Penelitian ini dibiayai oleh Pusat Penelitian Oseanografi LIPI melalui hibah dana DIPA tahun 2017 dengan nomor SP DIPA079.01.2.017106/2017. Semua penulis berkontribusi sama (kontributor utama) dalam penulisan naskah artikel ini. Triyoni Purbonegoro membimbing dan mengarahkan Anna Rejeki Simbolon dalam penulisan naskah artikel ini. 


\section{Daftar Pustaka}

Ahmad, F., Azman, S., Said, M. I. M., Baloo, L. (2015a). Tropical seagrass as a bioindicator of metal accumulation. Sains Malaysiana, 44(2), 203-210.

Ahmad, F., Azman, S., Said, M. I. M., Baloo, L. (2015b). Biomonitoring of metal contamination in estuarine ecosystem using seagrass. Journal of Environmental Health Science Engineering, 13, 1-4.

Alloway, B. J., \& Ayres, D. C. (1995). Chemical Principle of Environmental Pollution. 2nd Edition. London: Blackie Academic and Professional, Chapman \& Hall.

Analuddin, K., Sharma, S., Jamili., Septiana. A., Rianse, U., Nadaoka, K. (2017). Heavy metal bioaccumulation in mangrove ecosystem at the coral triangle ecoregion, Southeast Sulawesi, Indonesia. Marine Pollution Bulletin, 125(1-2), 472-480.

[ANZECC] Australian and New Zealand Environment and Conservation Council, [ARMCANZ] Agriculture and Resource Management Council of Australia and New Zealand. (2000). Australian and New Zealand Guidelines for Fresh and Marine Water Quality. Volume 1. Canberra: Australian and New Zealand Environment and Conservation Council.

Baker, A. J. (1981). Accumulators and excludersstrategies in the response of plants to heavy metals. Journal of Plant Nutrition, 3(1), 643-654.

Bonanno, G., \& Di Martino, V. (2016). Seagrass Cymodocea nodoca as a trace element biomonitor: bioaccumulation patterns and biomonitoring uses. Journal of Geochemical Exploration, 169, 43-49.

[BPLHD] Badan Pengelola Lingkungan Hidup Daerah. (2014). Laporan Status Lingkungan Hidup Daerah Provinsi Daerah Khusus Ibukota Jakarta Tahun 2014. Jakarta: BPLHD.

Chaudhuri, P., Nath, B., \& Birch, G. (2013). Accumulation of trace metals in grey mangrove Avicennia marina fine nutritive roots: the role of rhizosphere processes. Marine Pollution Bulletin, 79, 284-292.

Cordova, M. R., Eftiah, F. D. M., Zamani, N. P. (2017). Ability of mangrove apple as mercury bioindicator. Omni-Akuatika, 13(2), 137-143.

Davies, C. A., Tomlinson, K., \& Stephenson, T. (1991). Heavy metals in river tees estuary sediments. Environmental Technology, 12, 961-972.

Ding, Z., Wu, H., Feng, X., Liu, J., Liu, Y., Yuan, Y., Jiayong, P. (2011). Distribution of $\mathrm{Hg}$ in mangrove trees and its implication for $\mathrm{Hg}$ enrichment in the mangrove ecosystem. Applied Geochemistry, 26(2), 205- 212.

Fang, T. H., \& Chen, R. Y. (2010). Mercury contamination and accumulation in sediments of the East China Sea. Journal of Environmental Sciences, 22(8), 1164-1170.

Hadiwijaya, L., Salim., Ahmad. (2013). Karakteristik pantai gugusan Pulau Pari. Region, 5(1), 1-11.

Heriyanto, N. M., \& Subiandono, E. (2011). Penyerapan polutan logam berat $(\mathrm{Hg}, \mathrm{Pb}$ dan $\mathrm{Cu}$ ) oleh jenis-jenis mangrove. Jurnal Penelitian Hutan dan Konservasi Alam, 8(2),177-188.

Heriyanto, N. M., \& Suharti, S. (2013). Kandungan logam berat dan plankton pada ekosistem tambak bermangrove dan tambak tanpa mangrove (kasus di Tegal Tangkil, Cikiong, Poponcol, dan Kedung Peluk). Jurnal Penelitian Hutan dan Konservasi Alam, 10(2), 121-133.

Huang, J., Hopke, P. K., Choi, H. D., Laing, J.R., Cui, H., Zananski, T. J., Chandrasekaran, S. R., Rattigan, O. V., Holsen, T. M. (2011). Mercury $(\mathrm{Hg})$ emissions from domestic biomass combustion for space heating. Chemosphere, 84, 1694-1699.

Kristanti, R.A., Mursidi., Sarwono. (2007). Kandungan beberapa logam berat pada bakau (Rhizophora apiculata) di Perairan Bontang Selatan, Kalimantan Timur. Jurnal Kehutanan Unmul, 3(2), 185-200.

Larkum, A.W., D. Orth, \& C.M. Duarte. (2006). Seagrasses: biology, ecology, and conservation. Dordrecht: Springer.

Llagostera, I., Perez, M., Romero, J. (2011). Trace metal content in the seagrass Cymodocea nodosa: differential accumulation in plant organs. Aquatic Botany, 95, 124-128.

Martuti, N. K. T., Widianarko, B., Yulianto, B. (2016). Copper acumulation on Avicennia marina in Tapak, Tugurejo, Semarang, Indonesia. Waste Technology, 4(1), 40-45.

Mason, R. P., Kim, E. H., Cornwell, J., Heyes, D. (2006). An examination of the factors influencing the flux of mercury, methylmercury and other constituents from estuarine sediment. Marine Chemistry, $102,1-2$.

Natsir, N. A., \& Rijal, M. (2020). The quality of Kayeli Bay Waters: $\mathrm{Pb}$ and $\mathrm{Hg}$ accumulation in water, sediments, and 
seagrass (Enhalus acoroides) of Buru Island in Maluku. International Journal of Scientific \& Technology Research, 9(03), 114-120.

Nadaa, M. S., Nur Taufiq, S. P. J., Sri, R. (2021). Kondisi makrozoobentos (Gastropoda dan Bivalvia) pada ekosistem mangrove, Pulau Pari, Kepulauan Seribu, Jakarta. Buletin Oseanografi Marina, 10(1), 33-41.

Nugraha, A. H., Bengen, D. G., Kawaroe, M. (2017). Physiological response of Thalassia hemprichii on antrophogenic pressure in Pari Island, Seribu Islands, DKI Jakarta. Indonesian Journal of Marine Sciences, 22(1), 40-48.

Poedjirahajoe, E., Mahayani, N. P. D., Sidharta, B. R., \& Salamuddin, M. (2013). Tutupan lamun dan kondisi ekosistemnya di kawasan pesisir Madasanger, Jelenga, dan Maluku Kabupaten Sumbawa Barat. Jurnal Ilmu Teknologi Kelautan Tropis, 5(1), 2646.

Purbonegoro, T., \& Suratno. (2020). Health risk assessment related to total mercury $(\mathrm{THg})$ concentration in Clam (Periglypta crispata) from Kepulauan Seribu Regency, Indonesia. Squalen Bulletin of Marine and Fisheries Postharvest and Biotechnology, 15(1), 11-17.

[P2O] Pusat Penelitian Oseanografi LIPI. (2016). Keanekaragaman Hayati Laut Pulau Pari dan Pendugaan Stoknya. Laporan Program dan Kegiatan Loka Pengembangan Kompetensi Sumber Daya Manusia Oseanografi. LIPI. Jakarta.

Radulescu, C., Stihi, C., Popescu, I. V., Dulama, I. D., Chelarescu, E. D., Chilian, A. (2013). Heavy metal accumulation and translocation in different parts of Brassicaoleracea L. Romanian Journal of Physics. 58(9), 1337-1354.

Rezvani, M., \& Zaefarian, F. (2011). Bioaccumulation and translocation factors of cadmium and lead in Aeluropus littoralis. American Journal of Agricultural Economics, 2(4), 114-119.

Sachoemar, S. I. (2008). Karakteristik lingkungan perairan Kepulauan Seribu. Jurnal Air Indonesia, 4(2), 109-114.

Suratno, \& Irawan, A. (2018). Mercury concentration on Enhalus acoroides and
Thalassia hemprichii at Seribu Islands. IOP Conference Series: Earth and Environmental Science, 118 (012058), 1-5.

Simbolon, A. R. (2018). Analisis risiko kesehatan pencemaran timbal $(\mathrm{Pb})$ pada kerang hijau (perna viridis) di Perairan Cilincing Pesisir DKI Jakarta. Oseanologi dan Limnologi di Indonesia, 3(3), 197-208.

Simbolon, A. R. (2019). Bioakumulasi kadmium dan merkuri pada kerang hijau, serta analisis multi medium risiko kesehatan di kawasan pemukiman pesisir. Jurnal Riset Akuakultur, 14(2), 119-126.

Subiandono, E., Bismark, M., Heriyanto, N. M. (2013). Kemampuan Avicennia marina (Forsk.) Vierh. dan Rhizophora apiculata Bl. dalam penyerapan polutan logam berat. Jurnal Penelitian Hutan dan Konservasi Alam, 10(1), 93-102.

Taylor, S. R. (1964). Abundance of chemical elements in the continental crust: a new table. Geochimica et Cosmochimita Acta, 28(8), 1273-1285.

Tuapattinaya, P. M. J., Rumahlatu, D., Tulalessy, S. (2016). Bioaccumulation of cadmium heavy metal and its effect on the level of chlorophyll and carotenoids of Thalassia hemprichii in the waters of Ambon Island. International Journal of Engineering Science, 6(5), 28-33.

Tupan, C. I, \& Azrianingsih, R. (2016). Accumulation of deposition of lead heavy metal in the tissues of root, rhizomes, and leaves of seagrass Thalassia hemprichii (Monocotyledoneae, Hydrocharitaceae). Bioflux, 9(3), 580-589.

Voegborlo, R. B., Matsuyama, A., Adimado, A. A., Akagi, H. (2011). Determination of methylmercury in marine and freshwater fish in Ghana using a combined technique of dithizone extraction and gas-liquid chromatography with electron capture detection. Food Chemistry, 124(3), 12441248.

Zamani. N. P., Prartono, T., Arman, A., Ariesta, D. S., \& Wahab, I. (2018). Concentration of heavy metals on roots, stem and leaves of Enhalus acoroides, in Tunda Island, Banten bay. Jurnal Ilmu dan Teknologi Kelautan Tropis, 10(3), 769-784. 